\title{
Control of bovine brucellosis from 1998 to 2009 in the state of Mato Grosso do Sul, Brazil
}

\section{Controle da brucelose bovina no Estado de Mato Grosso do Sul, Brasil, de 1998 a 2009}

\author{
Jamil Manoel Leal Filho'; ${ }^{1}$ Ilda Francisca Neves Bottene'; \\ Letícia Almeida Retumba Carneiro Monteiro ${ }^{2}$; Aiesca Oliveira Pellegrin ${ }^{3}$; \\ Vitor Salvador Picão Gonçalves ${ }^{4}$; Fernando Ferreira ${ }^{5}$; Ricardo Augusto Dias ${ }^{5}$; \\ Marcos Amaku ${ }^{5}$; Evelise Oliveira Telles ${ }^{5}$; José Henrique Hildebrand Grisi-Filho; \\ Marcos Bryan Heinemann ${ }^{5}$; José Soares Ferreira Neto ${ }^{5 *}$
}

\begin{abstract}
This study used disease prevalence as an indicator to assess the effectiveness of the bovine brucellosis vaccination program implemented by the state of Mato Grosso do Sul. The state was divided into three regions: Pantanal, Planalto Sul, and Planalto Norte. For each region, a predetermined number of properties was sampled; in each, blood samples were collected from randomly selected cows aged at least 24 months. Sera from animals were subjected to a protocol that called for serial testing, with screening and confirmation using the buffered acidified antigen and 2-mercaptoethanol tests, respectively. In each property, a questionnaire was completed in order to identify risk factors associated with the disease. The overall prevalence rates of infected herds and infected animals in the state were $30.6 \%[27.4 ; 34.0]$ and $7.0 \%[5.6 ; 8.7]$, respectively. The regional prevalence rates of infected herds and infected animals were $39.1 \%$ and $8.9 \%$, respectively, in Pantanal, $25.3 \%$ and $6.1 \%$ in Planalto Sul, and $32.1 \%$ and $6.4 \%$ in Planalto Norte. Bovine brucellosis in the state is associated with the purchase of breeding animals, herd size, and beef and mixed types of enterprise. Thus, Mato Grosso do Sul should reassess its vaccination program in order to improve its effectiveness. The state must also increase education and supervision to encourage producers to test breeding animals for brucellosis before introducing them to their properties. Key words: Brazil. Bovine brucellosis. Mato Grosso do Sul. Prevalence. Risk factors. Vaccination.
\end{abstract}

\section{Resumo}

O estudo foi realizado para se verificar a eficácia do programa de vacinação contra brucelose bovina implementado pelo Mato Grosso do Sul, utilizando-se a prevalência como indicador. O Estado foi

\footnotetext{
${ }^{1}$ Auditor Fiscal Federal Agropecuário, Ministério da Agricultura, Pecuária e Abastecimento, MAPA, Campo Grande, MS, Brasil. E-mail: jamil.leal@agricultura.gov.br

2 Médicas Veterinárias, Agência de Defesa Sanitária Animal e Vegetal de Mato Grosso do Sul, IAGRO, Campo Grande, MS, Brasil. E-mail: ibottene@iagro.ms.gov.br; leticia.monteiro@iagro.ms.gov.br

${ }^{3}$ Pesquisadora, Empresa Brasileira de Pesquisa Agropecuária, EMBRAPA Pantanal, Corumbá, MS, Brasil. E-mail: aiesca@cpap. embrapa.br

${ }^{4}$ Prof., Faculdade de Agronomia e Medicina Veterinária, Universidade de Brasília, UNB, Brasília, DF, Brasil. E-mail: vitorspg@ unb.br

${ }^{5}$ Profs., Faculdade de Medicina Veterinária e Zootecnia, Universidade de São Paulo, USP, São Paulo, SP, Brasil. E-mail: grisi@, vps.fmvz.usp.br; fernando@vps.fmvz.usp.br; amaku@vps.fmvz.usp.br; dias@vps.fmvz.usp.br; evelise@vps.fmvz.usp.br; marcosbryan@usp.br; jsoares@vps.fmvz.usp.br

* Author for correspondence
} 
dividido em três regiões: Pantanal, Planalto Sul e Planalto Norte. Para cada região, foi amostrado um número preestabelecido de propriedades e em cada uma delas foram colhidas amostras de sangue de fêmeas com idade igual ou superior a 24 meses aleatoriamente selecionadas. Os soros dos animais foram submetidos a um protocolo de testes em série, com triagem pelo teste com Antígeno Acidificado Tamponado e confirmação pelo 2-Mercaptoetanol. Em cada propriedade foi aplicado um questionário para individualizar os fatores de riscos associados à doença. No estado, a prevalência de focos foi $30,6 \%[27,4 ; 34,0]$ e a de animais $7,0 \%[5,6 ; 8,7]$. As prevalências de focos e de animais nas regiões foram 39,1\% e 8,9\% no Pantanal, $25,3 \%$ e $6,1 \%$ no Planalto Sul e $32,1 \%$ e 6,4\% no Planalto Norte. A brucelose bovina no estado está associada à aquisição de reprodutores, ao tamanho do rebanho e ao tipo de exploração corte e mista. Assim, o Mato Grosso do Sul deve reavaliar seu programa de vacinação, buscando maior eficácia. Adicionalmente, o estado deve realizar um grande esforço de educação e de fiscalização para que os produtores testem os animais de reprodução para brucelose antes de introduzilos em suas propriedades.

Palavras-chave: Brucelose bovina. Prevalência. Fatores de risco. Vacinação. Mato Grosso do Sul. Brasil.

\section{Introduction}

Bovine brucellosis is a highly prevalent anthropozoonosis with worldwide distribution and is caused by the bacterium Brucella abortus. In cattle, the main signs of infection are abortion in the final third of gestation, retained placenta, stillbirths, and the birth of weak calves (PAULIN; FERREIRA NETO, 2003, 2002). The disease results in economic losses since it increases the calving interval, causing decreased calving rates as well as beef and milk production, in addition to increased animal replacement rates (FARIA, 1984). The disease also hinders the marketing of animals and their products and undermines the competitiveness of the country in the international market (LAGE et al., 2006).

Humans can be exposed by contact with infected animals or consumption of non-pasteurized milk. Cowboys, handlers, veterinarians, milkers, and slaughterers are high-risk occupations for infection by contact with the fetus, umbilical cord, and fetal fluid of infected cows and also because of accidents with live vaccines (PAULIN; FERREIRA NETO, 2003). The disease also leads to losses related to the cost of human treatment and the workplace absence during convalescence (PAULIN; FERREIRA NETO, 2003).

In 2001, the Ministry of Agriculture, Livestock and Supply (MAPA), aware of the need to adequately combat the disease, developed and launched the
National Program for the Control and Eradication of Brucellosis and Tuberculosis (PNCEBT) (LAGE et al., 2006).

Shortly after the launch of the PNCEBT, the MAPA instructed the Collaborating Center in Animal Health, School of Veterinary Medicine and Animal Science of the University of São Paulo to standardize a methodology and perform crosssectional studies in all units of the Federation, with the aim of choosing the most appropriate strategies and administrating the management processes (POESTER et al., 2009).

Thus, studies were performed in 17 Federative Units representing $75 \%$ of the Brazilian bovine herd. The results revealed infected herds prevalence rates of $0.32 \%$ and $41.2 \%$ in Santa Catarina and Mato Grosso, respectively (ALMEIDA et al., 2016; ALVES et al., 2009; AZEVEDO et al., 2009; BORBA et al., 2013; CLEMENTINO et al., 2016; DIAS et al., 2009a, 2009b; GONÇALVES et al., 2009a, 2009b; KLEIN-GUNNEWIEK et al., 2009; MARVULO et al., 2009; NEGREIROS et al., 2009; OGATA et al., 2009; ROCHA et al., 2009; SIKUSAWA et al., 2009; SILVA et al., 2009; VILLAR et al., 2009).

Mato Grosso do Sul (MS) opted to use data collected in 1998 because of the similarity of the methodology proposed by the Collaborating Center. Thus, Chate et al. (2009) analyzed data collected 
in 1998 and reported an infected herd prevalence of $41.5 \%$ [36.5; 44.7] in the state, placing it among the most prevalent in the country. Consequently, it was recommended that the state develop an efficient vaccination program using the B19 strain, aiming for an annual vaccination coverage rate of $80 \%$ for calves between 3 to 8 months of age. In addition, to help increase vaccine coverage, the state was also stimulated to vaccinate adult animals with the RB51 strain from 2007, and its use was regulated by the SDA Regulatory Instruction no. 33, of August 24, 2007.
In 2002, the state of Mato Grosso do Sul instituted a mandatory B19 vaccination program for all cattle and buffalo calves (MATO GROSSO DO SUL, 2002). However, sanctions were adopted only from 2004 (MATO GROSSO DO SUL, 2003). Verification of vaccination coverage is performed through the declaration of biannual vaccination performed by the rural producer with the official veterinary service, in such a way that vaccination coverage is calculated based on the total number of cows reported to be vaccinated compared to the target population; i.e., the total number of cows of sufficient age for vaccination. Figure 1 shows the results of this program in the state.

Figure 1. Bovine brucellosis vaccination in the state of Mato Grosso do Sul from 2002 to 2009.

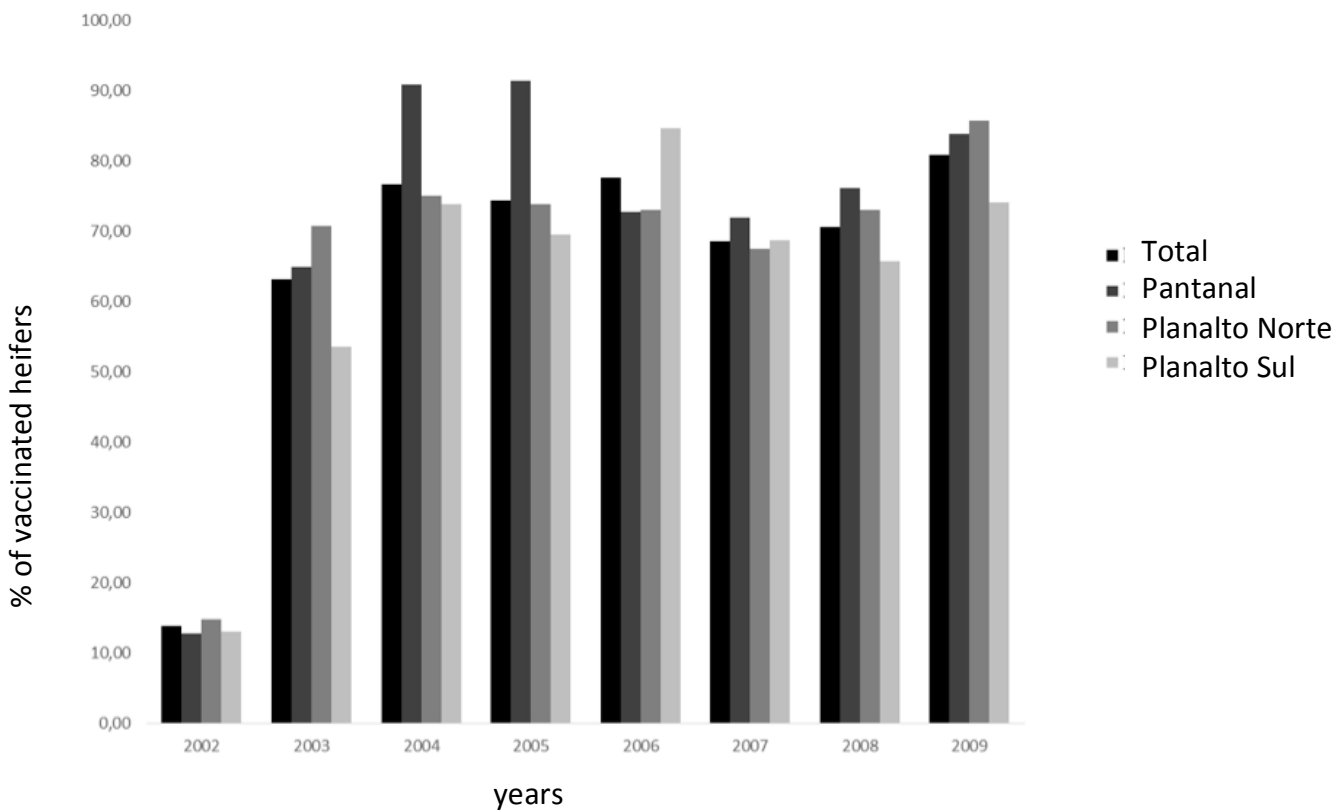

The states of Santa Catarina, São Paulo, Minas Gerais, Espírito Santo, Rondônia, Mato Grosso, and Rio Grande do Sul have also performed second studies to assess the prevalence of brucellosis. Of these, a decrease in the prevalence of infected herds due to vaccination was verified only in Mato Grosso, Minas Gerais, and Rondônia (BARDDAL et al., 2016; BAUMGARTEN et al., 2016; DIAS et al., 2016; ANZAI et al., 2016; INLAMEA et al., 2016; OLIVEIRA et al., 2016; SILVA et al., 2016).

Given the above, this study used prevalence as an indicator to evaluate the effectiveness of the vaccination program implemented by the state of Mato Grosso do Sul. Furthermore, it also aimed to individualize risk factors associated with bovine brucellosis. 


\section{Materials and Methods}

The study was planned by technicians from MAPA, the Collaborating Center for Animal Health, School of Veterinary Medicine and Animal Science of the University of São Paulo (FMVZUSP), and the state Agency for Animal and Plant Health Protection of Mato Grosso do Sul (IAGROMS). Fieldwork was carried out by technicians of IAGRO from August to September 2009.

The state was first divided into regions, taking into account the different production systems, management practices, type of operation, average herd size, the marketing system of the animals, and the operational capacity of the animal health protection service.

Within each of these regions, a pre-established number of properties with reproductive activity (primary sampling units) was selected randomly. This process was carried out based on the land register maintained by IAGRO properties. Within each selected property, a pre-established number of cows at least 24 months of age was selected randomly (secondary sampling units).

In rural properties with more than one herd, the herd of greater economic importance was chosen, in which the animals were submitted to the same management; i.e. under the same risks of exposure to infection. Randomly selected properties that could not be visited were replaced by a new property. The number of properties selected per region was estimated using the formula for simple random samples (THRUSFIELD, 2007). The parameters used for the calculation were: confidence level of 0.95 , an estimated prevalence of 0.20 , and an error of 0.05 .

The sample planning for the secondary units aimed to estimate a minimum number of animals to be examined on each property in order to allow their classification as infected with brucellosis. For this purpose, the concept of aggregated sensitivity and specificity was used (DOHOO et al., 2003). Test protocol sensitivity and specificity values of 0.95 and 0.995, respectively, were used (FLETCHER et al., 1998), along with an estimated prevalence of 0.20 . Herdacc version 3 was used to calculate the required sample sizes that resulted in herd sensitivity and specificity values equal to or better than $90 \%$. Thus, 10 animals were sampled from properties with up to 99 cows at least 24 months of age, while 15 animals were sample from properties with 100 or more cows at least 24 months of age. Cows in the peri-delivery period; i.e. approximately 15 days before and after delivery, were excluded from the selection.

Blood samples were collected from all selected animals through jugular vein puncture using a sterile disposable needle and placed in previously labeled vacuum tube. The sera obtained from the samples were frozen at $-20^{\circ} \mathrm{C}$ in polypropylene microtubes until the completion of the tests. The sera testing protocol including an initial screening using the buffered acidified antigen test (Rose Bengal), followed by retest of positive samples with the 2-mercaptoethanol test (2-ME). These tests were performed by the Laboratory of Diagnosis of Animal Diseases of IAGRO.

Properties were considered to be positive for disease when least one seropositive animal was detected. Those with only inconclusive and negative results were withdrawn from the analysis, along with animals with inconclusive results.

The sample planning enabled us to determine the prevalence of infected herds and adult cows ( $\geq 24$ months of age) seropositive for bovine brucellosis in the both state and in individual regions. The prevalence and respective confidence intervals were calculated as described by Dean et al. (1994). The prevalence of infected herds and animals in the state and of animals within the regions were estimated in a weighed manner, as described by Dohoo et al. (2003).

The weight of each property used to calculate the prevalence of infected herds in the state was given by: 


$$
P_{1}=\frac{\text { Properties in the region }}{\text { Properties sampled in the region }}
$$

The weight of each animal used to calculate the prevalence disease among animals in the state was given by:

$$
\begin{gathered}
P_{2}=\frac{\text { Cows } \geq 24 \text { months on the property }}{\text { Cows } \geq 24 \text { months sampled in property }} \mathrm{X} \\
\text { Cows } \geq 24 \text { months in the region }
\end{gathered}
$$

Cows $\geq 24$ months sampled in the region

In the expressions above, the first term refers to the weight of each animal in the calculation of prevalence of animals within the regions.

The estimates of prevalence and their respective 95\% confidence intervals were performed using EpiInfo 6.0 and SPSS, version 9.0. The prevalence rates were compared using the two-proportion test, also conducted using SPSS.

In each sampled property, in addition to blood sampling for serological examination, an epidemiological questionnaire was also applied in order to obtain information on the production system and management practices employed.

The variables analyzed were: type of production system (beef, dairy, or mixed), type of breeding (confined, semi-confined, extended), use of artificial insemination, predominant breeds, number of animals, presence of other domestic and wild species, occurrence of abortion in the past two years, disposal of placenta and aborted fetuses, purchase and sale of animals, vaccination against bovine brucellosis, sharing of pasture with other properties, occurrence of floods in pastures, presence of calving paddock, and veterinary care.
The variables were organized according to increasing scale of risk. When necessary, the variables were re-categorized. The category of lower risk was considered the basis for comparison with the other categories. The quantitative variables were categorized in percentiles. An exploratory analysis (univariate analysis) was performed to identify variables with $\mathrm{p}<0.20$ by $\chi 2$ or Fisher exact tests, which were included in subsequent logistic regression analysis. The calculations were performed using SPSS.

All field-based and laboratory data were inserted in a specific database, and used for the epidemiological analyses.

\section{Results}

The state was divided in three regions (Figure 2). Region 1 includes Pantanal, with its characteristic ebb and flow phenomena, where the main type of production is extensive breeding. Regions 2 and 3 are located in Planalto and both have significant milk production. In Planalto North, cattle breeding, rebreeding, and fattening predominate, while fattening and finishing predominates in Planalto Sul.

Table 1 provides a summary of the census data and samples studied. Table 2 shows the prevalence of infected herds and animals in the regions and the state overall. The prevalence of infected herds per type of breeding according to region is listed in Table 3.

Table 4 shows the final logistic regression model for risk factors associated with bovine brucellosis infection in the state of Mato Grosso do Sul. 
Figure 2. Map of Mato Grosso do Sul state and the regions used in this study, 2009.

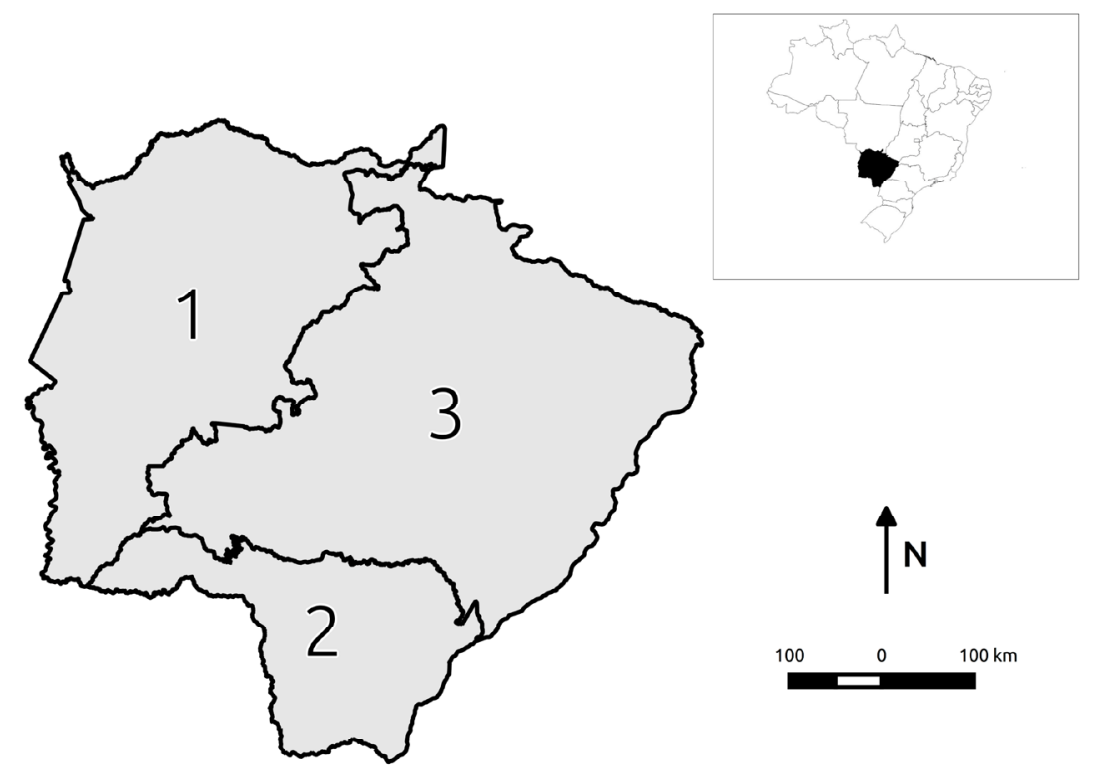

Table 1. Census data and the sample of the state of Mato Grosso do Sul, 2009.

\begin{tabular}{cccccc}
\hline Region & $\begin{array}{c}\text { Number of } \\
\text { Municipalities }\end{array}$ & $\begin{array}{c}\text { Properties with } \\
\text { reproductive } \\
\text { activity }\end{array}$ & $\begin{array}{c}\text { Sampled } \\
\text { properties }\end{array}$ & $\begin{array}{c}\text { Cows } \geq 24 \\
\text { months of age }\end{array}$ & $\begin{array}{c}\text { Sampled cows } \\
\geq 24 \text { months of } \\
\text { age }\end{array}$ \\
\hline Pantanal & 9 & 6,320 & 306 & $2,157,468$ & 3,501 \\
Planalto Sul & 31 & 18,976 & 319 & $1,491,708$ & 3,506 \\
Planalto Norte & 38 & 30,338 & 318 & $4,733,766$ & 3,018 \\
\hline Total & 78 & 55,634 & 943 & $8,382,942$ & 10,025 \\
\hline
\end{tabular}

Table 2. Prevalence of bovine brucellosis infected herds and infected animals according to regions in the state of Mato Grosso do Sul, 2009.

\begin{tabular}{lcccc}
\hline \multirow{2}{*}{ Region } & \multicolumn{2}{c}{ Properties } & \multicolumn{2}{c}{ Cows $\geq 24$ months of age } \\
\cline { 2 - 5 } & Prevalence (\%) & $95 \%$ CI (\%) & Prevalence (\%) & $95 \%$ CI (\%) \\
\hline Pantanal & 39.1 & $33.7-44.7$ & 8.9 & $5.9-13.2$ \\
Planalto Sul & 25.3 & $20.8-30.4$ & 6.1 & $4.1-9.0$ \\
Planalto Norte & 32.1 & $27.2-37.4$ & 6.4 & $4.7-8.6$ \\
\hline Total & 30.6 & $27.4-34.0$ & 7.0 & $5.6-8.7$ \\
\hline
\end{tabular}


Table 3. Prevalence of infected herds of bovine brucellosis stratified by type of operation according to region in the state of Mato Grosso do Sul, 2009.

\begin{tabular}{lcccccc}
\hline \multirow{2}{*}{ Region } & \multicolumn{5}{c}{ Prevalence of brucellosis infected herds (P) (\%) } \\
\cline { 2 - 7 } & \multicolumn{2}{c}{ Beef } & \multicolumn{2}{c}{ Dairy } & Mixed \\
\cline { 2 - 7 } & $\mathrm{P} \mathrm{( \% )}$ & $95 \%$ CI (\%) & P (\%) & $95 \%$ CI (\%) & P (\%) & $95 \%$ CI (\%) \\
\hline Pantanal & 50.0 & $42.8-57.2$ & 9.7 & $3.1-20.3$ & 32.7 & $20.3-47.1$ \\
Planalto Sul & 41.7 & $32.1-51.9$ & 14.1 & $8.9-20.7$ & 27.4 & $16.8-40.2$ \\
Planalto Norte & 42.2 & $34.5-50.1$ & 14.8 & $8.5-23.3$ & 25.0 & $14.4-38.4$ \\
\hline
\end{tabular}

Table 4. Multiple logistic regression analysis and risk factors associated with brucellosis infection in the state of Mato Grosso do Sul, 2009.

\begin{tabular}{lcc}
\hline \multicolumn{1}{c}{ Risk Factor } & OR & CI (95\%) \\
\hline Number of cows $\geq 24$ months of age & & \\
Up to 12 & & $0.94-2.46$ \\
13 to 35 & 1.51 & $1.5-3.81$ \\
36 to 169 & 2.37 & $2.56-6.72$ \\
170 or more & 4.12 & \\
Type of operation & & $1.21-3.18$ \\
Dairy & 1.96 & $1.9-4.41$ \\
Mixed & 2.88 & \\
Beef & & $1.04-1.94$ \\
Introduction of breeding animals & & \\
No & 1.42 & \\
Yes
\end{tabular}

\section{Discussion}

Despite the methodological differences between this study and the study performed in 1998 (CHATE et al., 2009), the results confirmed a decrease in the prevalence of infected herds in the state. The prevalence in 1998 was $41.5 \%$ [36.5; 44.7] and fell to $30.6 \%[27.4 ; 34.0]$ in the present study, based on fieldwork performed in 2009 (Table 2). This decrease was probably the result of the vaccination program implemented by the state in 2002. However, the prevalence rates are still very high, and the state should reassess its vaccination program in order to improve it effectiveness, as advocated by Amaku et al. (2009). Special attention should be given to the dissemination of the RB51vaccine in adult cows, since this practice positively impacts the reduction of prevalence (SOUZA et al., 2016). In the Pantanal region, where the management of animals is hampered by the ebb and flow regimen, implementation of vaccination of calves with RB51 within a larger age window than that used for the B19 vaccine should be considered.

Table 3 shows a clear concentration of infected herds in beef enterprises, followed by mixed enterprises, with lower prevalence observed in dairy farms. This finding is corroborated by the results of a study of risk factors, discussed below.

In addition to Mato Grosso do Sul, the states of São Paulo, Espírito Santo, Rondônia, Rio Grande do Sul, Mato Grosso, Minas Gerais, and Santa Catarina also performed a second study of the prevalence of brucellosis. The prevalence of infected herds decreased in Mato Grosso, Minas Gerais, and Rondônia, presumably due to vaccination (BARDDAL et al., 2016; BAUMGARTEN et al., 2016; DIAS et al., 2016; ANZAI et al., 2016; 
INLAMEA et al., 2016; OLIVEIRA et al., 2016; SILVA et al., 2016).

The final logistic regression model indicated that the purchase of breeding animals, herd size, and beef and mixed enterprises were associated with bovine brucellosis infection (Table 4).

The introduction of breeding animals has been reported as a classic risk factor for bovine brucellosis in the international literature (CRAWFORD et al., 1990; KELLAR et al., 1976; NICOLETTI, 1980). In Brazil, this variable was also verified as a risk factor for bovine brucellosis in the states of Bahia, Goias, Minas Gerais, Paraná, and São Paulo (ALVES et al., 2009; DIAS et al., 2009a, 2009b; GONÇALVES et al., 2009a; KLEIN-GUNNEWIEK et al., 2009; ROCHA et al., 2009). The problem is not the introduction of animals, a routine activity in cattle breeding, but rather the introduction without testing the animals or without knowing the sanitary condition of the herd of origin.

The association between herd size and brucellosis has been reported by several international studies (KELLAR et al., 1976; NICOLETTI, 1980; SALMAN; MEYER, 1984). In Brazil, this association was also observed in the states of Mato Grosso, Rio de Janeiro, Sergipe, Tocantins, São Paulo, and in 1998 study performed in Mato Grosso do Sul (CHATE et al., 2009; DIAS et al., 2009b; KLEIN-GUNNEWIEK et al., 2009; NEGREIROS et al., 2009; OGATA et al., 2009; SILVA et al., 2009). Some characteristics of larger herds facilitate the transmission of brucellosis, especially the increased need for animal replacement, increased difficulty in implementing disease control measures, and the inherent dynamics of brucellosis (CRAWFORD et al., 1990). Christie (1969) observed that increased herd size results in an increased probability of occurrence, persistence of infection, and difficulty in eradicating the disease. Therefore, the larger the herd, the greater the risk of introducing brucellosis and the greater the probability of its spreading within the herd.
The fact that beef and mixed enterprises, particularly beef, presented a higher risk of brucellosis infection compared to dairy farms probably results from larger herds. In the state, the median number of cows in beef properties was 117 in mixed 27 compared to 13 in dairy properties.

\section{Conclusions}

The results of this study demonstrated a reduction in the prevalence of brucellosis infected herds since 1998. Nevertheless, the prevalence of infected herds and infected animals remains high in the state. Thus, the state of Mato Grosso do Sul should reassess its vaccination program in order to improve its effectiveness. Special attention should be given to the dissemination of the RB51 vaccine in adult cows. In the Pantanal region, where management of the animals is hampered by the ebb and flow regimen, vaccination of calves with the RB51 vaccine, within a larger age window than the B19 vaccine, should be considered. Additionally, the state should increase education and supervision to encourage producers to test breeding animals for brucellosis before introducing them to their properties.

\section{Acknowledgements}

The authors acknowledge the logistical and financial support from MAPA, IAGRO-MS, CNPq and FAPESP.

\section{References}

ALMEIDA, E. C.; FREITAS, A. A.; PONTUAL, K. A. Q.; SOUZA, M. M. A.; AMAKU, M.; DIAS, R. A.; FERREIRA, F.; TELLES, E. O.; HEINEMANN, M. B.; GONÇALVES, V. S. P.; EVÊNCIO NETO, J.; MARVULO, M. F. V.; GRISI-FILHO, J. H. H.; FERREIRA NETO, J. S.; SILVA, J. C. R. Prevalence and associated risk factors for bovine brucellosis in the state of Pernambuco, Brazil. Semina: Ciências Agrárias, Londrina, v. 37, n. 5, p. 3413-3424, 2016. Suplemento 2. 
ALVES, A. J. S.; GONÇALVES, V. P. S.; FIGUEIREDO, V. C. F.; LÔBO, J. R.; BAHIENSE, L.; AMAKU, M.; FERNANDO, F.; FERREIRA NETO, J. S.; DIAS, R. A. Situação epidemiológica da brucelose bovina no Estado da Bahia. Arquivo Brasileiro de Medicina Veterinária e Zootecnia, Belo Horizonte, v. 61, p. 6-13, 2009. Suplemento 1.

AMAKU, M.; DIAS, R. A.; FERREIRA NETO, J. S.; FERREIRA, F. Modelagem matemática do controle da brucelose bovina por vacinação. Arquivo Brasileiro de Medicina Veterinária e Zootecnia, Belo Horizonte, v. 61, p. 135-141, 2009. Suplemento 1.

ANZAI, E. K.; COSTA, D.; SAID, A. L. P. R.; GRISI-FILHO, J. H. H.; AMAKU, M.; DIAS, R. A.; FERREIRA, F.; GALVIS, J. O. A.; GONÇALVES, V. S. P.; HEINEMANN, M. B.; TELLES, E. O.; FERREIRA NETO, J. S. An update on the epidemiological situation of bovine brucellosis in the state of Espírito Santo, Brazil. Semina: Ciências Agrárias, Londrina, v. 37, n. 5, p. 3437-3448, 2016. Suplemento 2.

AZEVEDO, S. S.; FERREIRA NETO, J. S.; DIAS, R. A.; FERREIRA, F.; AMAKU, M.; FIGUEIREDO, V. C. F.; LÔBO, J. R.; GONÇALVES, V. S. P.; SOUZA, A. C.; VASCONCELLOS, S. A. Situação epidemiológica da brucelose bovina no Estado do Espírito Santo. Arquivo Brasileiro de Medicina Veterinária e Zootecnia, Belo Horizonte, v. 61, p. 19-26, 2009. Suplemento 1.

BARDDAL, J. E. I.; SANTOS, J. C. Q.; LOPES, I. F.; FERREIRA NETO, J. S.; FERREIRA, F.; AMAKU, M.; DIAS, R. A.; TELLES, E. O.; GRISI-FILHO, J, H. H.; HEINEMANN, M. B.; GONÇALVES, V. S. P.; AGUIAR, D. M. Effect of vaccination in lowering the prevalence of bovine brucellosis in the state of Mato Grosso, Brazil. Semina: Ciências Agrárias, Londrina, v. 37, n. 5, p. 3479-3492, 2016. Suplemento 2.

BAUMGARTEN, K. D.; VELOSO, F. P.; GRISI-FILHO, J. H. H.; FERREIRA, F.; AMAKU, M.; DIAS, R. A.; TELLES, E. O.; HEINEMANN, M. B.; GONÇALVES, V. S. P.; FERREIRA NETO, J. S. Prevalence and risk factors for bovine brucellosis in Santa Catarina state, Brazil. Semina: Ciências Agrárias, Londrina, v. 37, n. 5, p. 3425-3436, 2016. Suplemento 2.

BORBA, M. R.; STEVENSON, M. A.; GONÇALVES, V. S. P.; FERREIRA NETO, J. S.; FERREIRA, F.; AMAKU, M.; TELLES, E. O.; SANTANA, S. S.; FERREIRA, J. C. A.; LÔBO, J. R.; FIGUEIREDO, V. C. F.; DIAS, R. A. Prevalence and risk-mapping of bovine brucellosis in Maranhão State, Brazil. Preventive Veterinary Medicine, v. 110, n. 2, p. 169-176, 2013.

CHATE, S. C.; DIAS, R. A.; AMAKU, M.; FERREIRA, F.; MORAES, G. M.; COSTA NETO, A. A.;
MONTEIRO, L. A. R. C.; LÔBO, J. R.; FIGUEIREDO, V. C. F.; GONÇALVES, V. S. P.; FERREIRA NETO, J. S. Situação epidemiológica da brucelose bovina no Estado do Mato Grosso do Sul. Arquivo Brasileiro de Medicina Veterinária e Zootecnia, Belo Horizonte, v. 61, p. 46-55, 2009. Suplemento 1.

CHRISTIE, T. E. Eradication of brucellosis in Northern Ireland: field problems and experiences. Veterinary Record, v. 85, p. 268-269, 1969.

CLEMENTINO, I. J.; DIAS, R. A.; AMAKU, M.; FERREIRA, F.; TELLES, E. O.; HEINEMANN, M. B.; GONÇALVES, V. S. P.; GRISI-FILHO, J. H. H.; FERREIRA NETO, J. S.; ALVES, C. J.; BEZERRA, C. S.; AZEVEDO, S. S. Epidemiological situation of bovine brucellosis in the state of Paraiba, Brazil. Semina: Ciências Agrárias, Londrina, v. 37, n. 5, p. 3403-3412, 2016. Suplemento 2.

CRAWFORD, R. P.; HUBER, J. D.; ADAMS, B. S. Epidemiology and surveillance. In: NIELSEN, K.; DUNCAN, J. R. (Ed.). Animal brucellosis. Boca Raton: CRC Press, 1990. p. 131-151.

DEAN, A. G.; DEAN, J. A.; COULOMBIER, D.; BRENDEL, K. A.; SMITH, D. C.; BURTON, A. H.; DICKER, R. C.; SULLIVAN, K.; FAGAN, R. F.; ARNER, T. G. Epi Info 6.: a word processing database, and statistics program for epidemiology on microcomputers. Atlanta: Center For Diseases Control And Prevention, 1994. 601 p.

DIAS, J. A.; MÜLLER, E. E.; DIAS, R. A.; FREITAS, J. C.; AMAKU, M.; FERREIRA, F.; SILVA, M. C. P.; LÔBO, J. R.; FIGUEIREDO, V. C. F.; GONÇALVES, V. S. P.; FERREIRA NETO, J. S. Situação epidemiológica da brucelose bovina no Estado do Paraná. Arquivo Brasileiro de Medicina Veterinária e Zootecnia, Belo Horizonte, v. 61, p .66-76, 2009a. Suplemento 1.

DIAS, R. A.; BELCHIOR, A. P. C.; FERREIRA, R. S.; GONÇALVES, R. C.; AGUIAR, R. S. C. B.; SOUSA, P. R.; SANTOS, A. M. A.; AMAKU, M.; FERREIRA, F.; TELLES, E. O.; GRISI-FILHO, J. H. H.; HEINEMANN, M. B.; GONÇALVES, V. S. P.; FERREIRA NETO, J. S. Controlling bovine brucellosis in the state of São Paulo, Brazil: results of ten years of vaccination program. Semina: Ciências Agrárias, Londrina, v. 37, n. 5, p. 3505-3518, 2016. Suplemento 2.

DIAS, R. A.; GONÇALVES, V. S. P.; FIGUEIREDO, V. C. F.; LÔBO, J. R.; LIMA, Z. M. B.; PAULIN, L. M. S.; GUNNEWIEK, M. F. K.; AMAKU, M.; FERREIRA NETO, J. S.; FERREIRA, F. Situação epidemiológica da brucelose bovina no Estado de São Paulo. Arquivo Brasileiro de Medicina Veterinária e Zootecnia, Belo Horizonte, v. 61, p. 118-125, 2009b. Suplemento 1. 
DOHOO, I.; MARTIN, W.; STRIYHN, H. Veterinary epidemiologic research. Charlottetown: Atlantic Veterinary College, 2003. 706 p.

FARIA, J. F. Situação da brucelose no Brasil. Comunicações Científicas da Faculdade de Medicina Veterinária e Zootecnia, São Paulo, v. 8, n. 2, p. 161-175, 1984.

FLETCHER, R. H.; FLETCHER, S. W.; WAGNER, E. H. Clinical epidemiology: the essentials. $2^{\text {th }}$ ed. Baltimore: Willians; Wilkkins, 1998. 246 p.

GONÇALVES, V. S. P.; DELPHINO, M. K. V. C.; DIAS, R. A.; FERREIRA, F.; AMAKU, M.; FERREIRA NETO, J. S.; PORTO, T. B.; ALVES, C. M.; FIGUEIREDO, V. C. F.; LÔBO, J. R. Situação epidemiológica da brucelose bovina no Estado de Minas Gerais. Arquivo Brasileiro de Medicina Veterinária e Zootecnia, Belo Horizonte, v. 61, p 35-45, 2009a. Suplemento 1.

GONÇALVES, V. S. P.; RIBEIRO, L. A.; CALDAS, R. A.; FRANCISCO, P. F. C.; DIAS, R. A.; FERREIRA, F.; AMAKU, M.; FERREIRA NETO, J. S.; FIGUEIREDO, V. C. F.; LÔBO, J. R.; BORGES, J. R. J. Situação epidemiológica da brucelose bovina no Distrito Federal. Arquivo Brasileiro de Medicina Veterinária e Zootecnia, Belo Horizonte, v. 61, p. 14-18, 2009b. Suplemento 1.

INLAMEA, O. F.; ROCHA, A. B.; FERREIRA, F.; GRISI-FILHO, J. H. H.; HEINEMANN, M. B.; DIAS, R. A.; TELLES, E. O.; GONÇALVES, V. S. P.; AMAKU, M.; FERREIRA NETO, J. S. Effect of vaccination in lowering bovine brucellosis in the state of Rondônia, Brazil. Semina: Ciências Agrárias, Londrina, v. 37, n. 5, p. 3493-3506, 2016. Suplemento 2.

KELLAR, J.; MARRA, R.; MARTIN, W. Brucellosis in Ontario: a case control study. Canadian Journal of Comparative Medicine, v. 40, p. 119-128, 1976.

KLEIN-GUNNEWIEK, M. F. C.; AMAKU, M.; DIAS, R. A.; FERREIRA, F.; GITTI, C. B.; PEREIRA, L. A; FIGUEIREDO, V. C. F.; LOBO, J. R.; GONÇALVES, V. S. P.; FERREIRA NETO, J. S. Situação epidemiológica da brucelose bovina no Estado do Rio de Janeiro. Arquivo Brasileiro de Medicina Veterinária e Zootecnia, Belo Horizonte, v. 61, p. 77-84, 2009. Suplemento 1.

LAGE, A. P.; ROXO, E.; MÜLLER, E.; POESTER, F.; CAVALlÉRO, J. C. M.; FERREIRA NETO, J. S.; MOTA, P. M. P. C.; GONÇALVES, V. S. P. Programa nacional de controle e erradicação da Brucelose e da tuberculose animal (PNCEBT). Brasília: Ministério da Agricultura, Pecuária e Abastecimento. 2006. 184 p. (Manual Técnico). Disponível em: $<$ http://www. agricultura.gov.br>. Acesso em: 5 ago. 2015.
MARVULO, M. F. V.; FERREIRA, F.; DIAS, R. A.; AMAKU, M.; GROFF, A. C. M.; GONÇALVES, V. S. P.; FIGUEIREDO, V. C. F.; LÔBO, J. R.; FERREIRA NETO, J. S. Situação epidemiológica da brucelose bovina no Estado do Rio Grande do Sul. Arquivo Brasileiro de Medicina Veterinária e Zootecnia, Belo Horizonte, v. 61, p. 93-102, 2009. Suplemento 1.

MATO GROSSO DO SUL. Governo do Estado de Mato Grosso do Sul. Portaria IAGRO/MS n²75/2002, de 02 de janeiro de 2002. Cuiabá, 2002. Disponível em: <http:// www3.servicos.ms.gov.br/iagro_ged/pdf/ 314_GED. pdf>. Acesso em: 22 jun. 2012.

Governo do Estado de Mato Grosso do Sul. Portaria IAGRO/MS n ${ }^{\circ} 636 / 2003$, de 26 de novembro de 2003. Cuiabá, 2003. Disponível em: <http://www3. servicos.ms.gov.br/iagro_ged/pdf/331_GED.pdf>. Acesso em: 22 jun. 2012.

NEGREIROS, R. L.; DIAS, R. A.; FERREIRA, F.; FERREIRA NETO, J. S.; GONÇALVES, V. S. P.; SILVA, M. C. P.; FIGUEIREDO, V. C. F.; LÔBO, J. R.; FREITAS, J.; AMAKU, M. Situação epidemiológica da brucelose bovina no Estado do Mato Grosso. Arquivo Brasileiro de Medicina Veterinária e Zootecnia, Belo Horizonte, v. 61, p. 56-65, 2009. Suplemento 1.

NICOLETTI, P. The epidemiology of bovine brucellosis. Advances in Veterinary Science and Comparative Medicine, v. 24, p. 69-98, 1980.

OGATA, R. A.; GONÇALVES, V. S. P.; FIGUEIREDO, V. C. F.; LÔBO, J. R.; RODRIGUES, A. L.; AMAKU, M.; FERREIRA, F.; FERREIRA NETO, J. S.; DIAS, R. A. Situação epidemiológica da brucelose bovina no Estado do Tocantins. Arquivo Brasileiro de Medicina Veterinária e Zootecnia, Belo Horizonte, v. 61, p. 126134, 2009. Suplemento 1.

OLIVEIRA, L. F.; DORNELES, E. M. S.; MOTA, A. L. A. A.; GONÇALVES, V. S. P.; FERREIRA NETO, J. S.; FERREIRA, F.; DIAS, R. A.; TELLES, E. O.; GRISIFILHO, J. H. H.; HEINEMANN, M. B.; AMAKU, M.; LAGE, A. P. Seroprevalence and risk factors for bovine brucellosis in the State of Minas Gerais, Brazil. Semina: Ciências Agrárias, Londrina, v. 37, n. 5, p. 3449-3446, 2016. Suplemento 2.

PAULIN, F. P.; FERREIRA NETO, J. S. O combate à brucelose bovina. Situação brasileira. Jaboticabal: Fundação de Estudos e Pesquisas em Agronomia, Medicina Veterinária e Zootecnia, 2003. 154 p.

PAULIN, L. M.; FERREIRA NETO, J. S. A Experiência brasileira no combate à brucelose bovina. Arquivos do Instituto Biológico, São Paulo, v. 69, n. 2, p. 105-112, 2002. 
POESTER, F.; FIGUEIREDO, V. C. F.; LÔBO, J. R.; GONÇALVES, V. S. P.; LAGE, A. P.; ROXO, E.; MOTA, P. M. P. C.; MÜLLER, E. E.; FERREIRA NETO, J. S. Estudos de prevalência da brucelose bovina no âmbito do programa nacional de controle e erradicação de brucelose e tuberculose: introdução. Arquivo Brasileiro de Medicina Veterinária e Zootecnia, Belo Horizonte, v. 61, p. 1-5, 2009. Suplemento 1.

ROCHA, W. V.; GONÇALVES, V. S. P.; COELHO, C. G. N. F. L.; BRITO, W. M. E. D.; DIAS, R. A.; DELPHINO, M. K. V. C.; FERREIRA, F.; AMAKU, M.; FERREIRA NETO, J. S.; FIGUEIREDO, V. C. F.; LÔBO, J. R.; BRITO, L. A. B. Situação epidemiológica da brucelose bovina no Estado de Goiás. Arquivo Brasileiro de Medicina Veterinária e Zootecnia, Belo Horizonte, v. 61, p. 27-34, 2009. Suplemento 1.

SALMAN, M. D.; MEYER, M. E. Epidemiology of bovine brucellosis in the Mexicali Valley, Mexico: literature review of disease-associated factors. American Journal of Veterinary Research, Chicago, v. 45, n. 8, p. 1557-1560, 1984.

SIKUSAWA, S.; AMAKU, M.; DIAS, R. A.; FERREIRA NETO, J. S.; MARTINS, C.; GONÇALVES, V. S. P.; FIGUEIREDO, V. C. F.; LÔBO, J. R.; FERREIRA, F. Situação epidemiológica da brucelose bovina no Estado de Santa Catarina. Arquivo Brasileiro de Medicina Veterinária e Zootecnia, Belo Horizonte, v. 61, n. 1, p. 103-108, 2009.
SILVA, N. S.; GROFF, A. C. M.; VIDOR, A. C. M.; GRISI-FILHO, J. H. H.; HEINEMANN, M. B.; DIAS, R. A.; TELLES, E. O.; GONÇALVES, V. S. P.; AMAKU, M.; FERREIRA, F.; FERREIRA NETO, J. S. Epidemiological situation of brucellosis after implementation of the vaccination program in Rio Grande do Sul State, Brazil. Semina: Ciências Agrárias, Londrina, v. 37, n. 5, p. 3519-3530, 2016. Suplemento 2.

SILVA, V.G. S. O.; DIAS, R.A.; FERREIRA, F.;AMAKU, M.; COSTA, E. L. S.; LÔBO, J. R.; FIGUEIREDO, V. C. F.; GONÇALVES, V. S. P.; FERREIRA NETO, J. S. Situação epidemiológica da brucelose bovina no Estado de Sergipe. Arquivo Brasileiro de Medicina Veterinária e Zootecnia, Belo Horizonte, v. 61, p. 109-117, 2009. Suplemento 1.

SOUZA, V. A. F.; FERREIRA NETO, J. S.; AMAKU, M.; DIAS, R. A.; TELLES, E. O.; GRISI-FILHO, J. H. H.; HEINEMANN, M. B.; FERREIRA, F. Mathematical modeling of bovine brucellosis control using the RB51 vaccine. Semina: Ciências Agrárias, Londrina, v. 37, n. 5, p. 3767-3776, 2016. Suplemento 2.

THRUSFIELD, M. Veterinary epidemiology. $3^{\text {th }}$ ed. Oxford: Blackwell Science, 2007. 610 p.

VILLAR, K. S.; AMAKU, M.; DIAS, R. A.; FERREIRA NETO, J. S.; BENITEZ, F.; GONÇALVES, V. S. P.; FIGUEIREDO, V. C. F.; LÔBO, J. R.; FERREIRA, F. Situação epidemiológica da brucelose bovina no Estado de Rondônia. Arquivo Brasileiro de Medicina Veterinária e Zootecnia, Belo Horizonte, v. 61, p. 85-92, 2009. Suplemento 1. 
